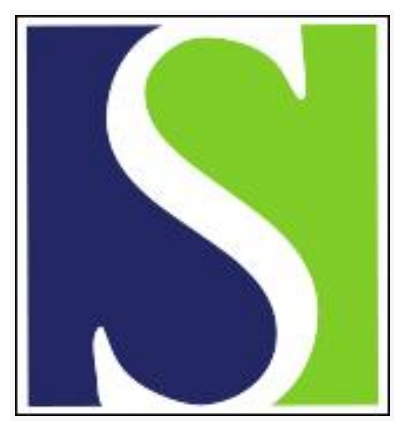

Scand J Work Environ Health 1977;3(1):16-22

https://doi.org/10.5271/sjweh.2797

Issue date: Mar 1977

A clinical, neurophysiological and behavioral study of female workers exposed to 1,1,1-trichloroethane.

by Maroni M, Bulgheroni C, Cassitto MG, Merluzzi F, Gilioli R, Foa' V

Key terms: 1,1,1-trichloroethane; behavioral study; clinical study; exposure; female worker; neurophysiological study; neurotoxicity; woman; women

This article in PubMed: www.ncbi.nlm.nih.gov/pubmed/139679

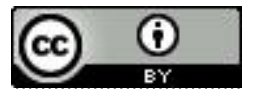




\title{
A clinical, neurophysiological and behavioral study of female workers exposed to 1,1,1-trichloroethane
}

\author{
by MARCO MARONI, M.D., CARLO BULGHERONI, M.D., M. GRAZIA \\ CASSITTO, Psychologist, FRANCA MERLUZZI, M.D., RENATO GILIOLI, \\ M.D., and VITO FOA', M.D. ${ }^{1}$
}

\begin{abstract}
MARONI, M., BULGHERONI, C., CASSITTO, M. G., MERLUZZI, F., GILIOLI, R. and FOA', V. A clinical, neurophysiological and behavioral study of female workers exposed to 1,1,1-trichlonoethane. Scand. $j$. work environ. \& health 3 (1977) 16-22. Twenty-two female subjects working in a factory in which 1,1,1-trichloroethane was the only solvent used were investigated by means of clinical, neurophysiological and psychometric methods so that the meurotoxicity of the solvent could be evaluated. On the basis of the ambient air concentrations of 1,1,1-trichloroethane ranging from 110 to $990 \mathrm{ppm}$, the workers were divided into three risk groups and compared with a reference group. No significant difference was observed between the exposed and unexposed females with respect to clinical features, maximal motor conduction velocity, conduction velocity of slow fibers, and psychometric data. The most frequent complaints of the workers were of the "neurotic" type with a slightly higher, but not significant, difference in the exposed group. The results obtained favor the absence of a manifest neurotoxic effect of 1,1,1-trichloroethane under the specific work conditions of the investigation; generally unfavorable work conditions seem to have played a prominent role in the genesis of the neurotic complaints. The importance of a global methodological approach in the study of work-related risks, panticularly in neurological and psychological surveys, is stressed.
\end{abstract}

Key words: female workers, neurotoxicity, 1,1,1-trichlonoethane.

Much existing data indicate that 1,1,1trichloroethane (methylchloroform) is one of the less toxic chlorinated solvents both for animals and humans $1,7,14,19,21$ ). For this reason it is widely used in industry and there is a tendency to replace the other more toxic chlorinated solvents, in particular trichloroethylene, with it.

This substance, previously also utilized as an anesthetic $(6,11)$, acts upon the central nervous system. Therefore studies have been carried out on volunteers to evaluate the performance after ex-

1 Institute of Occupational Health, Milan, Italy.

Reprint requests to: Dr. Vito Foa', Clinica del Lavoro "L. Dovoto," Via S. Barnaba, 8, Milano, Italy. posure to low levels of 1,1,1-trichloroethane. A mild sedative effect was reported by the DEG-Kommission (5) after repeated exposure to $500 \mathrm{ppm}$. On the other hand Stewart et al. (20) and Salvini et al. (17) observed no important changes in volunteers exposed respectively to 500 $\mathrm{ppm}$ for $7 \mathrm{~h}$ daily for 5 days and for $8 \mathrm{~h}$ for 1 day. Salvini et al. did however detect a very mild impairment in the performance of the volunteers when they were engaged in a mental task. Using psychomotor tests, Gamberale and Hultengren (9) also observed impairment in the performance of volunteers exposed for $30 \mathrm{~min}$ to concentrations ranging from 250 to $500 \mathrm{ppm}$. Such impairment appeared at $350 \mathrm{ppm}$. 
While many experimental data are available, very few studies of groups occupationally exposed to 1,1,1-trichloroethane have been reported in the literature (18). In addition the studies that have been reported have dealt with male workers only. Therefore, using clinical, psychometric and neurophysiological methods, we investigated the female workers of a factory in which 1,1,1-trichloroethane has been the only solvent used for a number of years.

\section{MATERIAL AND METHODS}

\section{Exposure}

The factory where the subjects work manufactures platinic and steel spinnerets for the production of synthetic fibers. The workers are involved with forging or pressing, punching and drilling and with sand-blasting and polishing. 1,1,1-Trichloroethane is employed as a lubricating agent for the drill-bit in the punching and drilling and as a degreasing agent in the polishing.

The drilling takes place in sections $A$ and $B$, the size of section $A$ being $20 \times$ $4 \times 3.5 \mathrm{~m}$ and section $B$ being made up of three rooms with the respective sizes of $12 \times 4 \times 4.5, \quad 8 \times 4 \times 4.5$, and $5 \times 4 \times$ $4.5 \mathrm{~m}$.

The polishing takes place in two small sections (C and D), $6 \times 4 \times 3.5$ and $4 \times$ $4 \times 4.5 \mathrm{~m}$ in size, respectively. In these sections the solvent is contained in tanks supplied with hood-formed exhaust fans located about $40 \mathrm{~cm}$ above the tanks.
After dipping the spinnerets in the tanks, the workers take them out and dry them with compressed air.

In all four sections, general exhaust fans are lacking with the exception of little fans at the windows.

For the past 6 years only 1,1,1-trichloroethane has been employed for these operations. Annual consumption has averaged $15,000-20,000 \mathrm{dm}^{3}$.

The 1,1,1-trichloroethane air concentrations, obtained during the month of June, are reported in table 1 , in which sound pressure levels and microclimatic conditions are also presented. For these determinations we collected several air samples at a height of $1.5 \mathrm{~m}$ above the floor level. Each sample consisted of $100 \mathrm{dm}^{3}$ of air pumped, with an aspiration pump, into two serial Drechseltubes, each containing $40 \mathrm{ml}$ of NN dimethylformamide.

The solutions were analyzed by gas chromatography and compared with standard solutions.

\section{Subjects}

We studied all the exposed subjects, i.e., 22 female workers in sections $\mathrm{A}, \mathrm{B}, \mathrm{C}$ and D. Their mean age was 32.4 years $( \pm 9.9$ SD) and the mean length of exposure was 6.7 years $( \pm 2.5 \mathrm{SD})$.

On the basis of the 1,1,1-trichloroethane concentrations in the air of the sections in which the women were employed, we divided the exposed workers into three groups. The seven workers in section A became group $I$, the workers in the second and third rooms of section $B$ and the

Table 1. Environmental conditions.

\begin{tabular}{lcccc}
\hline Section & $\begin{array}{c}\text { Number of } \\
\text { workers }\end{array}$ & $\begin{array}{c}1,1,1 \text {-trichloroethane } \\
\text { air concentration } \\
(\mathrm{ppm})\end{array}$ & $\begin{array}{c}\text { Corrected } \\
\text { effective } \\
\text { temperature }\end{array}$ & $\begin{array}{c}\text { Sound } \\
\text { pressure } \\
\text { level } \\
\text { (dB-A) }\end{array}$ \\
\hline A & 7 & 110 & 24 & - \\
B (1st room) & 7 & $200-345$ & 24 & 73 \\
B (2nd room) & 3 & 140 & 24.5 & 82 \\
B (3rd room) & 2 & 160 & 24.5 & 82 \\
C & 2 & 140 & 23.7 & $85-94$ \\
D & 1 & $720-990$ & 24 & 90 \\
E & 3 & 0 & 24.5 & $83-84$ \\
F & 4 & 0 & 24.5 & 70 \\
\hline
\end{tabular}


workers of section C (a total of seven women) comprised group II, and group III (8 subjects) consisted of the workers in the first room of section $B$ plus those in section $D$.

The reference group was composed of seven female workers with a mean age of 31.4 years ( $\pm 12.6 \mathrm{SD}$ ). The women worked in the same factory as the exposed subjects but had no past or present exposure to any solvent. Three of them were engaged in punching control (section $\mathrm{E}$ ), and the remainder were employed in offices as accountants (section F).

\section{Methods}

The investigation consisted of a questionnaire on subjective symptoms and work conditions, a general physical examination, determination of 1,1,1-trichloroethane metabolites in the urine, a neurological examination, an electrodiagnostic study, and psychological tests.

The subjects filled out a two-part questionnaire on subjective complaints and work conditions. The first section of the questionnaire concerned work organization, physical and mental stress, posture, microclimatic comfort, presence of dust, gases, vapors, or bad smells in the work environment, etc. The second part had 57 questions regarding the most common symptoms affecting the respiratory, digestive, circulatory, sexual, locomotor, skin, sensory and nervous systems. The possible answers were "never present," "seldom present" and "often present." The answers were interpreted as positive when "often present" was stated.

During the general physical examination a case history was taken that included information on living habits, daily intake of alcohol and coffee, smoking habits, drug consumption, and possible nonoccupational exposure to neurotoxic agents.

The urine samples for the determination of 1,1,1-trichloroethane metabolites, i.e., trichloroethanol (TCE) and trichloroacetic acid (TCA) $(10,12,18)$ were collected at the end of a shift on Friday after five days of work. The analysis was performed by gas chromatography (3), but some samples were also checked with the Fujiwara method (12).
The neurological examination was mainly centered on the search for signs revealing peripheral neuropathy, i.e., the evaluation of muscular strength according to an $0-4$ scale, the determination of deep tendon reflexes, and a sensory examination of superficial (pin, touch, temperature, twopoint descrimination) and deep sensation (vibration and sense of position).

The electrodiagnostic study consisted of the assessment of the maximal motor conduction velocity (MCV) of the ulnar and common peroneal nerves and the conduction velocity of the slow motor fibers (CVSF) of the same nerves. The CVSF was determined according to the desynchronization principle (13).

The psychological test battery was composed of a general intelligence test (Raven PM 38) (15), two subtests of the Wechsler Intelligence Scale, namely Picture Completion and Block Design (22), two personality inventories that detect possible neurotic traits (Eysenck's Maudsley P. I.) (8) and anxiety levels (Cattell's IPAT) (4), two psychomotor ability tests (Pauli test and Symbol-Number Association) (2), and a memory test, i.e., Rey PRM 1 (16). There were a total of 23 test variables.

All the subjects filled out the questionnaires at the factory on the same afternoon. During the days that followed, the workers who took the psychological tests in the morning were submitted in the afternoon to the physical examination and the neurological and neurophysiological evaluation.

\section{RESULTS}

There was no difference between the groups of workers exposed to 1,1,1-trichloroethane and the reference group with respect to the daily consumption of alcohol, coffee and tobacco; however this was never particularly relevant.

In table 2 the subjective complaints of the exposed and reference groups are presented. In general the most frequent complaints were of the neurotic type, the exposed group having a slightly higher, but not significant, frequency than the reference group. Only the complaint of lowback pain was statistically more frequent among the exposed than among the nonexposed $(p<0.05)$. 
Table 2. Frequency of subjective disturbances stated by the female workers.

\begin{tabular}{|c|c|c|}
\hline $\begin{array}{l}\text { Subjective } \\
\text { disturbance }\end{array}$ & $\begin{array}{c}\text { Exposed } \\
\text { females } \\
(\mathrm{N}=22) \\
\%\end{array}$ & $\begin{array}{c}\text { Nonexposed } \\
\text { femalles } \\
(\mathrm{N}=7) \\
0 \%\end{array}$ \\
\hline Headache & 81.8 & 57.1 \\
\hline Anxiety & 77.3 & 57.1 \\
\hline $\begin{array}{l}\text { Nervousness and } \\
\text { irritability }\end{array}$ & 54.5 & 42.9 \\
\hline $\begin{array}{l}\text { Psychic } \\
\text { depression }\end{array}$ & 36.4 & 28.6 \\
\hline Insomnia & $\begin{array}{l}00.4 \\
36.4\end{array}$ & $\begin{array}{l}20.0 \\
28.6\end{array}$ \\
\hline Eye irritation and & & \\
\hline $\begin{array}{l}\text { lacrimation } \\
\text { Digestive }\end{array}$ & 54.5 & 42.9 \\
\hline disorders & 45.5 & 28.6 \\
\hline Low-back pain & 45.5 & $14.3^{*}$ \\
\hline
\end{tabular}

The physical examination revealed the following diseases among the exposed group: 3 cases of hypertension, 3 cases of gastritis, 2 cases of cervical spondylosis, 1 case of arthritis in both hands, 2 cases of cholecystitis, 1 case of eczema, and 1 case of dyskeratosis of the hands. Among the reference group 1 case of hypertension, 1 case of gastritis, and 1 case of cervical spondylosis were diagnosed.

Neither TCA nor TCE were detected in the urine of the reference group. In the exposed groups TCA was found only in five urinary samples in amounts ranging from 10 to $30 \mathrm{mg} / \mathrm{dm}^{3}$ and no TCE value exceeded $10 \mathrm{mg} / \mathrm{dm}^{3}$.

The neurological examination did not reveal any sign that could be attributed to central or peripheral nervous system impairment.

In our laboratory the neurophysiological parameters have the following normal values: common peroneal nerve: $\mathrm{MCV}$ $\max >40 \mathrm{~m} / \mathrm{s}$, CVSF $30 \mathrm{~m} / \mathrm{s}$; ulnar nerve: MCV $\max >45 \mathrm{~m} / \mathrm{s}$, CVSF $>35 \mathrm{~m} / \mathrm{s}$. None of the examined subjects had MCV or CVSF values outside the normal range.

In tables 3 and 4 the neurophysiological results obtained for the exposed and reference groups are presented. A statistical analysis (Kruskal-Wallis one-way analysis of variance for small groups) demonstrated the lack of any significant difference between the exposed and the nonexposed workers (level of significance $p<0.01$ ).
Table 5 shows the means and standard deviations of the results of the psychological tests. The analysis of variance was also applied to these results, but no significant difference was observed between the exposed and reference groups (level of significance $p<0.01$ ).

A risk index was constructed which accounted for the length of exposure and the concentration of the solvent in the air. Three levels of exposure in a ratio scale of $1,0.5,0.25$ were determined and then multiplied by the length of exposure in years.

The partial correlation coefficients of the risk index and psychometric data after the elimination of the effect of age were not significant at the $1 \%$ level of significance. On the other hand, for all the groups considered the mean values of the performances on the administered tests and the mean values of the scores on the personality inventories fell within the normal range of the reference population. Psychomotor performances were also unaffected.

\section{DISCUSSION}

The aim of our study was to evaluate the potential neurotoxicity of 1,1,1-trichloroethane in an occupationally exposed female population. The results obtained by means of the described methodology, in particular the electrophysiological and psychometric parameters, showed no detectable changes in the central and peripheral nervous functions of the exposed group.

Our results agree with the experimental data of Stewart et al. (20) and Salvini et al. (17) and indicate the absence of a manifest neurotoxic effect of 1,1,1-trichloroethane in workers continuously exposed for 6 years to air concentrations ranging from 110 and $345 \mathrm{ppm}$. Only one worker studied by us (from group III) was exposed to higher levels (from 720 to $990 \mathrm{ppm}$ ), but she had normal neurophysiological findings.

However definite conclusions on the neurotoxicity of 1,1,1-trichloroethane cannot be drawn from our study because the population was small and had been exposed for only a moderate length of time. 
Table 3. Electrophysiological parameters of the ulnar nerve.

\begin{tabular}{|c|c|c|c|c|}
\hline \multirow[b]{2}{*}{ Parameter } & \multirow{2}{*}{$\begin{array}{c}\text { Nonexposed } \\
\text { female workers }\end{array}$} & \multicolumn{3}{|c|}{ Femalle workers exposed to 1,1,1-trichloroethane } \\
\hline & & $\begin{array}{l}\text { Group I } \\
(110 \text { ppm) }\end{array}$ & $\begin{array}{c}\text { Group II } \\
(140-160 \mathrm{ppm})\end{array}$ & $\begin{array}{l}\text { Group III } \\
(200-990 \mathrm{ppm})\end{array}$ \\
\hline \multicolumn{5}{|l|}{$\operatorname{MCV}(\mathrm{m} / \mathrm{s})^{a}$} \\
\hline $\begin{array}{l}M \\
\mathrm{SD} \\
\mathrm{N}\end{array}$ & $\begin{array}{c}62.61 \\
8.31 \\
7\end{array}$ & $\begin{array}{l}64.86 \\
5.74 \\
7\end{array}$ & $\begin{array}{c}64.77 \\
11.81 \\
7\end{array}$ & $\begin{array}{c}62.39 \\
10.53 \\
8\end{array}$ \\
\hline \multicolumn{5}{|c|}{$\operatorname{CVSF}(\mathrm{m} / \mathrm{s})^{b}$} \\
\hline $\begin{array}{l}\mathrm{M} \\
\mathrm{SD} \\
\mathrm{N}\end{array}$ & $\begin{array}{c}41.72 \\
7.13 \\
6\end{array}$ & $\begin{array}{c}46.01 \\
4.75 \\
5\end{array}$ & $\begin{array}{c}40.92 \\
9.18 \\
7\end{array}$ & $\begin{array}{c}42.76 \\
9.57 \\
8\end{array}$ \\
\hline \multicolumn{5}{|l|}{ Age (yeans) } \\
\hline $\begin{array}{l}\mathrm{M} \\
\mathrm{SD}\end{array}$ & $\begin{array}{l}31.43 \\
12.63\end{array}$ & $\begin{array}{r}30.00 \\
7.79\end{array}$ & $\begin{array}{l}38.29 \\
11.67\end{array}$ & $\begin{array}{r}29.62 \\
8.91\end{array}$ \\
\hline \multicolumn{5}{|c|}{$\begin{array}{l}\text { Employment time } \\
\text { (years) }\end{array}$} \\
\hline $\begin{array}{l}\mathrm{M} \\
\mathrm{SD}\end{array}$ & $\begin{array}{l}6.14 \\
4.26\end{array}$ & $\begin{array}{l}7.43 \\
3.05\end{array}$ & $\begin{array}{l}6.29 \\
1.25\end{array}$ & $\begin{array}{l}6.50 \\
2.88\end{array}$ \\
\hline
\end{tabular}

a $\mathrm{MCV}=$ maximal motor conduction velocity.

b $\mathrm{CVSF}=$ conduction velocity of the slow fibers.

Table 4. Electrophysiological parameters of the common peroneal nerve.

\begin{tabular}{|c|c|c|c|c|}
\hline \multirow[b]{2}{*}{ Parameters } & \multirow[b]{2}{*}{$\begin{array}{l}\text { Nonexposed } \\
\text { female workers }\end{array}$} & \multicolumn{3}{|c|}{ Female workens exposed to 1,1,1-trichloroethane } \\
\hline & & $\begin{array}{l}\text { Group I } \\
(110 \mathrm{ppm})\end{array}$ & $\begin{array}{c}\text { Group II } \\
(140-160 \mathrm{ppm})\end{array}$ & $\begin{array}{c}\text { Group III } \\
(200-990 \mathrm{ppm})\end{array}$ \\
\hline \multicolumn{5}{|l|}{$\operatorname{MCV}(\mathrm{m} / \mathrm{s})^{a}$} \\
\hline $\mathbf{M}$ & 53.59 & 53.74 & 60.33 & 56.67 \\
\hline $\mathrm{SD}$ & 5.64 & 4.80 & 4.26 & 3.98 \\
\hline $\mathrm{N}$ & 7 & 6 & 7 & 8 \\
\hline \multicolumn{5}{|l|}{$\operatorname{CVSF}(\mathrm{m} / \mathrm{s})^{b}$} \\
\hline M & 48.84 & 44.63 & 45.27 & 51.99 \\
\hline $\mathrm{SD}$ & 5.29 & 5.39 & 6.61 & 2.75 \\
\hline $\mathbf{N}$ & 7 & 6 & 7 & 8 \\
\hline \multicolumn{5}{|l|}{ Age (years) } \\
\hline $\mathrm{M}$ & 31.43 & 28.67 & 38.29 & 29.62 \\
\hline $\mathrm{SD}$ & 12.63 & 7.61 & 11.67 & 8.91 \\
\hline \multicolumn{5}{|c|}{$\begin{array}{l}\text { Employment time } \\
\text { (years) }\end{array}$} \\
\hline M & 6.14 & 7.67 & 6.29 & 6.50 \\
\hline SD & 4.26 & 3.27 & 1.25 & 2.88 \\
\hline
\end{tabular}

a $\mathrm{MCV}=$ maximal motor conduction velocity.

b CVSF $=$ conduction velocity of the slow fibers. 
Table 5. Means and standard deviations of the results of the psychological testing.

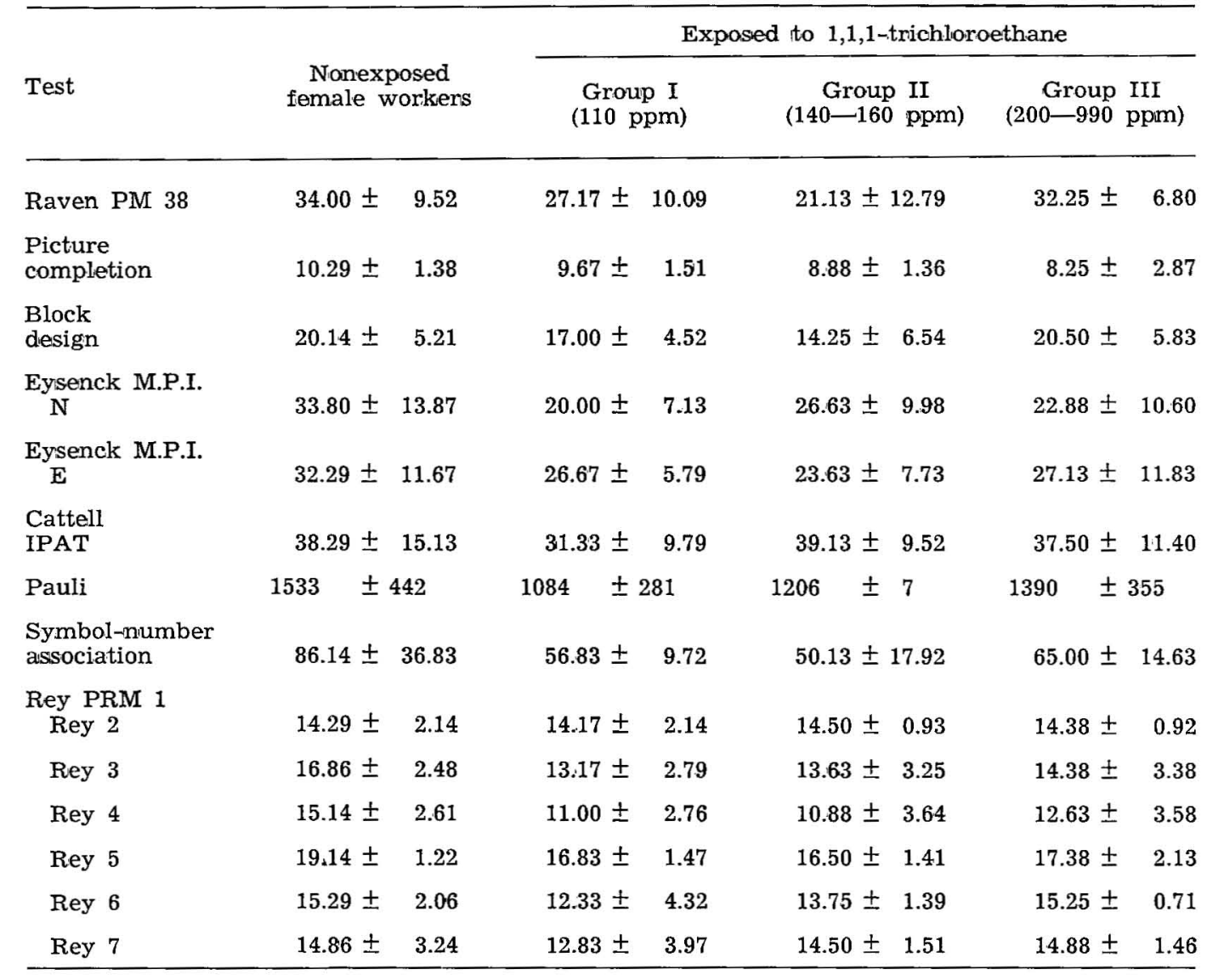

Further epidemiologic surveys are needed to confirm these preliminary results.

The subjective complaints of the workers deserve some comment. The most frequent disturbances were of the "neurotic" type (headache, anxiety, nervousness, irritability, insomnia, psychic depression, digestive disorders, etc.). The nonsignificant difference in the frequency of the disorders observed in the exposed and the reference groups excluded a neurotoxic action of the solvent as the genesis of the symptoms. However, neurotic complaints were so frequent in the total population that one must consider the role of unfavorable environmental and work conditions. This interpretation is confirmed by the questionnaire answers in reference to work conditions and by the results of the microclimatic and noise determinations.

In fact the workers listed the unfavor- able conditions that they considered a source of discomfort, for example, the bad smell of the solvent, the insufficient dimensions of the workplace, the monotony and the low degree of gratifications, the unsanitary conditions, the use of the microscope for $8 \mathrm{~h}$ daily, etc.

The microclimatic determinations revealed a corrected effective temperature that was higher than 21 , and therefore the microclimate conditions were certainly a source of discomfort for most of the workers. Moreover, excessive noise was present in all the sections and it even reached levels potentially dangerous to the hearing in sections C and D (table 1). We therefore believe that the psychoneurotic disorders found were mainly due to the generally unfavorable work conditions.

The conclusions of our study do not favor a consistent neurotoxic action of 
1,1,1-trichloroethane in circumstances similar to those in our investigation, but they do confirm the necessity for establishing a "global" methodological approach to the study of work-related risks. This approach is particularly important in studies where neurological and psychological parameters are mainly used, since other factors such as motivation, work organization, etc., always interfere. Even when investigating the effect of a neurotoxic agent, the study must always account for the complex work conditions because all the factors present within the work environment play a definite role.

\section{REFERENCES}

1. ADAMS, E. M., SPENCER, H. C., ROWE, V. K. and IRISH, D. D. Vapour toxicity of trichloroethane (methylchloroform) determined by experiments on laboratory animals. Arch. ind. hyg. 1 (1950) 225.

2. ARNOLD W. Der Pauli Test. Johan Ambrosius Berth, München 1970. 185 p.

3. BUCHET J. P., LAUWERYS R. and ROELS H. Le dosage par chromatographie en phase gaseuse des metabolites urinaires du trichloroethylene: l'acide trichlonoacetique et le trichloroethanol. Mal. prof. 35 (1974): 3, $395-402$.

4. CATTELL, R. B. The IPAT anxiety scale. Institute for personality and ability testing, Champaign, Ill. 1957. 32 p.

5. DEUTSCHE FORSCHUNGSGEMEINSCHAFT - KOMMSSION GESUNDHEITSSCHADLICHE ARBEITSSTOFFE Toxikologish arbeitsmedizinische Begrunddung von MAK-Werten. Verlag Chemie, Weinheim 1972.

6. DORNETTE, W. H. L. and JONES, J. P Clinical experiences with 1,1,1-trichloroethane: A preliminary report of 50 anesthetic administrations. Anesth. analg. curr. res. 39 (1960) 249.

7. EBEN, A. and KIMMERLE, G. Excretion and toxicology of methylchloroform in acute and subacute exposed rats. Arch. toxicol. 31 (1974) 233.

8. EYSENCK, H. J. Manual of the Maudsley personality inventory. University of London Press Ltd., Londion 1959. $15 \mathrm{p}$.

9. GAMBERALE, F. and HULTENGREN, M. Methylchloroform exposure: II. Psychological functions. Work-environ.-health 10 (1973) $82-92$
10. HAKE C. L., WAGGONER, T. B., ROBERTSON, D. N. and ROWE, V. K. The metabolism of 1,1,1-trichloroethane by the rat. Arch. environ. health 1 (1960) 101.

11. KRANTZ. J. C. JR., PARK. C. S. and LING, J. S. L. Anesthesia LX: The anesthetic properties of 1,1,1-trichloroethane. Anesthesiology 20 (1959) 635.

12. IKEDA, M. and OHTSUJI, H. A comparative study of the excretion of Fujiwara reaction-positive isubstances in urine of humans and rodients given trichloro- or tetrachloro-derivates of ethane and ethylene. $\mathrm{Br} j$. ind. med. 29 (1972) 99-104.

13. PINELLI, $P$. Ricerche sul reclutamento delle unità motorie del muscolo nell'uomo in condizioni normali e patologiche (con particolare riguardo all'adduttore del pollice). Riv. pat. nerv. ment. 76 (1953) 601

14. PRENDERGAST, J. A., JONES, R. A., JEKINS, L. $J$ and SIEGEL, $J$ Effects on experimental animals of long-term inhalation of trichloroethylene, carbon tetrachloride, 1,1,1-trichloroethane, dichlorodifluoromethane and 1,1 dichloroethylene. Toxicol. appl. pharmacol. 10 (1967) 270.

15. RAVEN, J. C. Progressive matrices 38. Lewis \& Co., London 1962. 14 p.

16. REY, A. Les troubles de la memoire et leur examen Psychometrique. Charles Dessant, Bruxelles 1966. 195 p.

17. SALVINI, M., BINASOHI, S. and RIVA, M. Evaluation of the psychophysiological functions in humans exposed to the TLV of 1,1,1-trichloroethane. $\mathrm{Br} . j$. ind. med. 28 (1971) 286.

18. SEKI, Y., URASHIMA, Y., AIKAWA, H., MATSUMURA, H., ICHIKAWA, Y. MIRATSUKA, F., YOSHIOKA, Y., SHIMBO, S. and IKEDA, M. Trichlorocompounds in the urine of humanis exposed to methylchloroform at subthreshold levels. Int. Arch. Arbeitsmed. 34 (1975) 39-49.

19. STEWART, R. D., GAY, H. H., ERLEY, D. S., HAKE, C. L and SGHAFFER, A. W. Human exposune to 1,1,1-trichloroethame vapour: Relationship of expired air and blood concentrations to exposure and toxicity. Am. ind. hyg. ass. j. 22 (1961) $252-$ 262.

20. STEWART, R. D., GAY, H. H., SCHAFFER, A. W., ERLEY, D. S. and ROWE, V. K. Experimental human exposure to methylchloroform vapor. Arch. environ. health 19 (1969) 467.

21. TORKELSON, T. R., OYEN, F., MC COLLISTER, D. D. and ROWE, V. K. Toxicity of 1,1,1-trichloroethane as determined on laboratory animals and human subjects. Am. ind. hyg. ass. j. 19 (1958) 353.

22. WECHSLER, D. Measurement of adult intelligence. (manual ed.). Organizzazioni Speciali, Firenze 1958. 74 p.

Received for publication: 1976-04-06 